choroid, but it has been detected in irises and in the dark pigment separated from the choroid by rubbing. The retinas (minus the back pigmented layer, which adheres to the choroid) contain none; they contain more phosphorus than the choroids, similar proportions of magnesium, sodium, and potassium, but less calcium and iron.

Comparing the choroids of cattle of different ages from about three to seven years, the barium, as stated above, increases with the age, and, generally, as the barium increases the quantities of sodium, potassium, magnesium, calcium, iron, and copper appear to decrease : further work on this point is necessary and we hope to obtain eyes from much older animals. The first choroids analysed came from an ox of unknown age, and they contained the largest proportion of barium so far found and the smallest quantities of the other elements named.

Zbinden ${ }^{2}$ did not find barium in cow's milk, but the strongest barium lines do not lie in the region of the spectrum in which he worked. Messrs. Adam Hilger, Ltd., in a recent letter to one of us on another subject, state that barium has been detected in cow's milk which had turned sour in glass bottles but not in fresh milk. Barium, to our knowledge, has not previously been detected in animal tissues, and its occurrence in quantity in the choroids, etc., of cattle is all the more remarkable. We are hopeful that the work described and projected may give information bearing on the mechanism of colour vision.

Hugh Ramage.

J. H. SHELdoN.

Carrow Hill, Norwich.

Regis Road, Wolverhampton, July 30.

1 NATCRe, April 20, 1929, p. 601.

? Le Lait, 11, No. 102, pp. 113-124; 1931.

The Double Lateral Line of Lepidosiren.

A FEW days ago when examining a small male specimen of Lepidosiren, one of three which I brought alive on May 1 from the island of Marajo at the mouth of the Amazon River, and which are now living in the Zoological Society's Aquarium, I noticed that it had two lateral lines on each side, one slightly dorsal to the middle of the side, the other near to the mid-ventral line. Since then I have examined more thoroughly a much larger female specimen, and have observed a few more details. The course of the sensory tubes is marked by lines of intense black, contrasting sharply with the light brown of the rest of the skin when the colour is in its pale phase. The principal lateral line, which may be described as dorso-lateral, branches out over the head into the usual three tracts, one above the eye, one between the eye and the mouth, and one below the mouth, or supra-ocular, maxillary, and mandibular. The ventro-lateral line at its anterior end anastomoses with the mandibular branches of the dorso-lateral. Each of the lateral lines is associated with short branches which are obliquely transverse to its course, but these short streaks are slightly separated from the main dorso-lateral line and dorsal to it; in the case of the ventro-lateral line, they are ventral to the line, and arise directly from it. A series of similar short oblique streaks occur on either side of the mid-dorsal line of the fish, but not a continuous line.

The description of Paraguay specimens by Sir Ray Lankester, published in 1898,1 does not mention the lateral line, but the large figure of the entire fish which illustrates the description shows only one lateral line without branches. This is surprising, because in Lankester's paper special attention is given to a paper by E. Ehlers, published in $1894,^{2}$ and Ehlers' paper contains a detailed description of the double lateral line in specimens from Paraguay. This description agrees very closely with that which I have given above, except that he does not mention the short streaks on either side of the mid-dorsal line of the fish, which suggest a third line of the dermal sensory system. Ehlers believed that $L$. paradoxa was a distinct species, to which some of the Paraguay specimens belonged, and in these the system of lateral lines was not distinctly recognisable. My own observations appear to constitute the first recognition of the multiple lateral line system in specimens of Lepidosiren from the Amazon region, and tend to confirm the opinion that there is no specific difference between the Lepidosiren of that region and those of the swamps of Paraguay. I am much indebted to Mr. R. H. Burne of the Royal College of Surgeons Museum for his kind help in investigating the literature of the subject.

35 Wavendon Avenue, Chiswick, W.4, July 22.

1 Trans. Zool. Soc., vol. 14, p. 11.

Ann. and Mag. Nat. Hist., Ser. 6, vol. 14, 1894, p. 6.

\section{Age of Certain Gravels in the New Forest Area.}

WHILE I rejoice to learn that Mr. Burkitt and his pupils are studying the Hampshire gravels, ${ }^{1}$ I hope he will forgive me if I question whether his letter adds materially to our knowledge of the sequence of events in this difficult area.

The separation of the gravel into two layers, with or without a sandy layer between, is of frequent occurrence throughout the district, from Stoney Cross to the coast; and often, but by no means always, the upper layer is the coarser and less stratified. Since the lower has a fluviatile aspect through a considerable range of level above the existing rivers, I infer that it belongs to a period of depression of the land, with consequent aggradation : and we can date this period by the fact that unrolled Acheulean implements have been found under the gravel. Implements found in the gravel itself are usually more or less rolled, especially perhaps those from the upper layer, but we can seldom say definitely (and certainly not at Stoney Cross or Pickets Post) from which horizon the tools come. Mousterian specimens are extremely rare, but not, I think, entirely absent.

Facts have been published ${ }^{2}$ pointing to the erosion of the main valleys down to about $50 \mathrm{ft}$. above the present rivers in, or before, Acheulean times; but Mr. Burkitt appears to go further, and to imply that the sea on the south coast of England (and even in the Solent River as far as Hordle) had reached its present level in late Chellean times; in which case the main valleys, in such soft strata, must inevitably have followed suit. But I do not see that he offers any evidence for this, or for his second postulate of a submergence " to a depth of at least $100 \mathrm{ft}$." before Acheulean times.

Finally, his correlation of the layer of sand $(c)$ at Hordle with the $100 \mathrm{ft}$. raised beach at Brighton must be received with caution, (1) because a similar layer is found in neighbouring gravels (Setley, Beaulieu Heath, etc.) up to $140 \mathrm{ft}$. O.D.; and (2) bocause, unless there is clear proof that the sand is marine, we must make allowance for a possible gradient of the Solent River, the mouth of which was many miles farther east.

HenRy Bury.

The Gate House,

Bournemouth West.

${ }^{2}$ NATURF, 128, 222, Aug. 8, 1931.

2 Proc. Prehist. Soc. E. Anglia, pp. 23 et seq., 1923.

No. 3226, VoL. 128] 